DOI : 10.14746/ps.2018.1.4

\title{
ON THE NATURE OF THE INTERNATIONAL SYSTEM
}

Among many tools at International Relations researcher's disposal, systemic analysis seems to be the most complex one. Bertalanaffy (physiologist by training), pioneer in systemic approach across sciences, remarked that in every discipline one is forced to deal with complex set-ups, "wholes" or "systems", and therefore, a significant change in approach towards scientific thinking is needed (1984: 33). It is not different with regard to the International Relations. Among many attributes of that way of perceiving reality (using system analysis allows broad range of interactions being observed and interpreted), the most tempting one is the hope to predict future outcomes of the present structure (usually by extrapolating observed trends).

The drive to create accurate forecasts might actually be as old as the discipline of international relations itself; however, despite many attempts, hypothetical models seem to remain negatively verified in practice. Behaviourists, despite the fact that they have attempted to shift their focus to the empirical side of research, could not escape these results as well, and their work remains criticised quite harshly for this reason. Methodologists, especially in Poland, tend to label methods of thinking used by the behaviourists, just to mention one, which is to be found in one of Gardocki's paper: "[...] inductive methods, which dominated behaviourist and post-behaviourist approach, are "turning" towards holistic studies, most often looking at the international system itself or its subsystems, and are rather detailed descriptions and because of that knowledge that derives from that seems to be loosely connected with "real systems and certain phenomena of social world. [...] It tends to lean towards philosophical explanations that can at most bring intellectual satisfaction" (Kraus-Mozer, 1992: 64). Statements like those mentioned above, are not unusual and they are sometimes quite fair; however, their existence can be justified by the fact that International Relations still have not become fully independent from social sciences (the methodological conflict between them seems to be in place, since they are looking at similar things from different perspectives). Basically, it boils down to dichotomy of the two approaches: reductionism/ holistic approach and inductive/deductive reasoning.

I. Wallerstein takes us to the origin of those disputes dating back to the 19th century, when the social sciences seemed to be positioned between natural sciences and humanities. This was not very comfortable because, scholars have never actually produced a separate methodological approach, a sort of "third way" of gathering and working with data. Instead, they simply split into those with a more scientific and those with a humanistic approach. The author notes that, "[t]he social sciences seemed tied into two horses straining in opposite directions, and pulled apart by them" (2004: 4). It 
is worth noting though, that behaviourists have pushed for more precise and rigorous interpretation of international relations by advocating more ontologically, epistemologically and methodologically-aware choices (Gardocki, 2012: 133).

There was a great deal of research on possibilities of predicting the future of international relations, and despite the fact that many interdisciplinary methods were tested, the extrapolation proves to be used most often (probably because of its convenience). After years of quantitative research, the conclusion that predicting the future of international relations is still not possible and the maximum to be expected is to get results in the real-time. This outcome surely has a lot of causes, but emphasis should be put explicitly on the following two: firstly, studying international relations is conducted in the state of limited information (both in terms of quality and quantity) and secondly, models of interactions are usually created by referring to the past events. Donaj concludes that most of the time predictions are rather trips to the future "in the vehicle fuelled by extravagant fantasy" (2017: 43). It is virtually impossible for the situation to be different when experience, observation and common sense, intuition and authority (things highly immeasurable) are laying at the foundation of forecasting (Donaj, 2017: 50).

Systemic approach towards International Relations is one of the most challenging approaches that is to be found within the discipline. It requires not only a broad knowledge in certain field, but also a capability to connect facts from other fields. The uselessness of most of the theoretical models along with their triviality, creates information noise, and theses built with the use of certain models are being repeated in other studies continuously, pulling researchers away from valuable conclusions. Reductionism seems to be a reasonable choice considering given circumstances. The results of reductionist methods are the base for a broader and more general research (it is difficult to imagine findings in modern physics without comprehending basic Newtonian linear mechanics).

Cybernetics, seen as a methodological approach, deals with problems in the reversed order. Instead of beginning with recognising the details of every little element in each subsystem, it creates most simple and digestible scheme of how things actually work. If certain assumptions seems to be accurate, it goes deeper into details. This approach has many drawbacks but it provides an alternative to reductionism, which has clearly dominated the discipline. It is also elegant and simple to use, thanks to a holistic point of view which is at the core of the idea.

It would be a misconception to think that cybernetics appeared from nowhere, together with an ideal, one-size-fits-all method. Its emergence was prompted by the problem of ongoing divisions in sciences, being a result of adopting more reductionist approach. Cybernetics reach into various disciplines and thanks to that, it has a potential to be a universal way for understanding complex systemic issues. One of the most beneficial side of adopting cybernetic approach is that it does not examine single elements in great depth over and over again. Rather, it is designed to use data which was already gathered and analysed by scholars in other fields (how many times we do things from the scratch instead of using findings of others). Cybernetics is also blind to moralism and normative approach. It strives to answer the question "how something is working?", instead of "how something should be working?". 
The aim of the following article is not to merely glorify the systemic approach in international relations, but rather to discuss the possibilities of developing this concept. I do understand that every level of analysis has its own difficulties, and systemic level is no different in that matter. As Bertalanaffy points out, "problem with the system is essentially problem of analytical constraints within the sciences in general" (1984: 47).

Strict systemic approach towards the dynamics in the field of the international relations is still not fully developed, despite the fact that the word "system" itself is commonly used. Political scientists also use systemic analysis despite the fact that there is actually no literature about sufficient use of that method. It results in a common misconception that we can substitute many concepts with the word "system" even if a structure that we look at consists of elements which do not interact with each other. Many errors connected with the use of some terms are even more visible within the concept of "levels of analysis," which try to answer whether there are qualitatively different mechanisms present in the given system. That differentiation was made by $\mathrm{K}$. Waltz in his doctoral dissertation "Man, the State and War." When looking at the causes of wars, he advised to take into account three dimensions: human behaviour, state's internal system and international system (Haliżak, 2012: 5), (Czaputowicz, 2012: 1-2; Gordecki, 2012: 134). In this way Waltz distinguished personal, state and international system levels. He advocated that in order to successfully analyse international relations, all of those aspects need to be looked at. The concept became very popular and today it lays at the core of the neorealist paradigm. Despite the criticism that Waltz had faced (for quite a modest description of the international's system structure), his idea prevailed. Quite different, and more advanced, concept was later constructed by Kaplan; he had created six heuristic models of the international system, underlining that each one of them had a different blueprint, when it comes to its interactions, and the reason behind it was, in his opinion, the structural influence on its elements.

At the very core of the international relations analysis, with the levels of analysis in place, there is very little said about the concept of system in the precise meaning of the word. In political science, the use of the word "system" is being justified in the following way: political system is a system because it has some connections, which the parts of a greater whole, and it is political because those mutual connections are in a relation to division of authority, wealth and resources with in society (Heywood, 2006: 30). Without agreeing on solid theoretical basis, scholars will continuously fall into the trap, which, in some sense, they are guilty of setting on themselves, like in the case of "black box" idea.

The concept which proves that it is possible to accurately observe the inside of a system just by looking at outcomes it produces can lead to gaining some knowledge but does not take us closer to analyse structure we are dealing with in depth. Before any conclusions about the structure of the system can take place, first it might be useful to introduce oneself to the theoretical basis created by professionals dealing with the systems in general, to fill "black box" with the elements that exist, at least theoretically. In political science, analysis of a given system in the situation of limited information on the systems' elements; structure and boarders along with its dynamics is being currently worked out within the "grey systems theory" scheme (Donaj, 2017: 48). Waltz himself underlines 
importance of future-oriented perspective, claiming that every approach that aspires to be systemic, has to have an ability to accurately forecast outcomes of the behaviours observed in international politics on systemic level (2010: 55).

By adopting knowledge offered by cybernetics (especially social cybernetics developed in Poland in the 60s and 70s), systemic analysis can get a whole new meaning from the perspective of international relations. I mentioned that most of the models are rather limited when it comes to describe broader occurrences. Among other factors, it can be ascribed to the fact that no valid model of abstract system itself was introduced into international relations. Therefore, I would like to present a model of that kind, developed by social cybernetics school and present its features very briefly. The following concept is not perfect, and there are significant challenges to be overcame in order to implement it, but it is worth looking at as it has a significant explanatory potential. Following paper is at the same time another step towards constructing cybernetic theory of international system structure.

J. Czaputowicz points out that according to Waltz, there are three main features of international system: rule of order in the system (anarchic or hierarchic); similarity (diversification or functional similarity) and division of power within the system (2012: 6). On top of that, other categories could be added: cyclical or random order (oscillational or fluctuational), topography of the system (linear or fractal) and stability type (homeostatic or heterostatic). I do agree with Waltz thesis that order in the international system is based on anarchy (no official submission between the states). However, I believe that its structure is fractal, oscillational and heterostatic. Division of power is understood here as the effect of the aforementioned factors. Below I briefly describe three additional dimensions of analysis with basic methodological difficulties that will have to be met at some point in the future as its aim is to look at the system more precisely. Despite the fact that Waltz is an advocate of reductionism in research, he admits openly that international system should be examined in the way that cybernetics looks at the systems (2010: 45).

\section{CONCEPT OF SYSTEMS}

There is number of definitions regarding word "system," which differ according to selected features depending on what one considers crucial (political, social, international etc.). In the strict sense, system is a set of elements interacting with one another via established connections. R. Acoff defines the system in a following way: "System is a set of elements between which there are interactions. Every element is connected to every other one directly or indirectly" (Gomółka, 1996: 21). Just by looking at this sentence some conclusions can be made. Firstly, every system consists of connected elements. Set with one element in it is not a system, same applies to an empty system. Secondly, elements of the given set have to be connected, and last but not least - some feedback loops need to be observed within the set to call it a system.

The main goal of every system is to counter the expanding entropy, both inside and outside of it. Wiener puts it this way: "We have known that some organisms, like human organism for instance, have tendency to upkeep (at least for some time) or even 
extend level of self-organisation that create an enclave in ongoing stream of advancing entropy, chaos and similarity. Life is an island in the dying world" (1950: 103-4).

Before moving forward to discuss the feedback loops as a separate topic, examination of elements of the system is needed. According to cybernetics, every system transforms energy and information (and sometimes matter too). Every system is transforming the energy and information and entrance/exit are simplified terms for specific organs that are responsible for those actions. Energy is being received by the feeder (kept by accumulator) and receptor simply receives information. At the other end there is an effector, that is the last chain of the entire transformation. Those very basic organs (there is a lot more of them) can be found on all levels of analysis (human beings, state system and international system).

\section{LINEAR OR FRACTAL?}

As mentioned above, the system transforms energy and information. Putting the inner structure of a singular system aside, for a time being, it is worth to ask the following question: where does the system gets the needed energy and information from, and where does it send to? Taking into account the assumption that system is surrounded by other systems, conclusion could be, that energy and information are gained at other systems expense and sent back to them too. Ackoff proposes differentiating systems between the opened and the closed ones, based on whether or not the system is surrounded (Gomółka, 1996: 21). It makes even more sense, if one considers the conservation of energy. Sending it into the void in not only impossible, but also would not be productive from the system's perspective, and it would also counter the strive to fight entropy which we mentioned in the upper paragraph. If systems are connected, there is an obvious question about quantity and quality of those connections. It seems that social systems are connected in a different way than mechanical appliances; instead of being connected in a circuit or a parallel, they create a network. This kind of connection leads to a three-dimensional picture of system complication. At first, each network seems to look like a flat surface that spreads endlessly. When observing the structure from a close distance overall complexity cannot be fully seen. Only when one increases the distance, one can see other systems coming into picture, and all of them are somehow connected with the first one we observed. The greater the distance the bigger this cluster of systems becomes. This might imply that the super-system (like international system) has a fractal structure, and that is why it cannot be treated as separate entity. If the structure of the systems is fractal, research on self-similarity should be conducted. In fact, are not the organisations working on a local level somehow similar with those working globally? Isn't a local community a smaller version of a nation? Finally, aren't elements of the system similar to the system itself? If so, the international system has to be similar to its elements too. Machine, just like the living organism, is a thing that on a local scale and for a certain period of time, tries to counter the entropy. Thanks to its ability to make decisions it can (in the world of vanishing differences) create local sphere of increased organisation (Wiener, 1960: 35). 
As international relations are dealing with the research on interactions between actors in the international environment, some types of division seem to be needed; however, it is virtually impossible to isolate one element, and study it without taking the impact of its surroundings into consideration Firstly, highly complex systemic interactions with - which international relations is dealing with, are non-linear. It means that actions are irregular, appear in somewhat different intensity, and probably they are connected with problem of different potentials (simplest example could be a negative and positive charge). By separating the system from its surrounding, one can see only a static picture of the given system in a specific moment in time (with hope that many of those pictures combined, will create a sort of motion and therefore - a dynamic view), without any past or future to look at. Conclusion could be as follows: observing international system as a whole cannot be conducted without its subsystems' dynamics, which also has to be seen in space and time (and so on). Bertalanaffy thought that the wholes called systems are built out of elements in the state of constant interactions, and that their organisation is "nontrivial" (non-linear). This nontriviality is also one of the main characteristics of fractal structure. To prove that, I quote all 5 basic fractal features below (Falconer, 2003: 25):

1) It has nontrivial (non-linear) structure in every scale;

2) Structure is too irregular to be described with the use of classic geometry;

3) It is self-similar, if not completely at least in statistical or stochastic way;

4) It has simple recurrence definition (self-reference P.B.);

5) Its fractal dimension exceeds its topographical dimension (multi-folded sort of P.B.).

It is also quite difficult to disagree with A. Gałganek's definition of structure, which implies that it is a constant relation between elements of the system which are of a similar nature (1992: 31).

\section{HOMEOSTATIC VERSUS HETEROSTATIC}

Concept of homeostasis is not a new thing, over many years it has proved to be useful in many fields. In biology, for instance, it is understood as a dynamic balance, based on mutual impact, between the external factors, which are focused on changing internal environment, and internal control mechanisms, which are working actively to prevent such changes (Campbell Biology, 2017: 876). It is worth mentioning that Wiener himself is believed to be the author of that concept. If structure of the system is measured by its organisation, the system is striving towards homeostasis: internal and external balance, continuously fighting entropy that is gradually shutting the system down. "Structure kept together by homeostasis is criterion of our personality as individuals" (Wiener, 1960: 104). On that basis, the question whether the international system is striving towards order or disorder is founded. Answer would imply the ultimate aim of occurring conflicts. There is an interesting proposition that international system, being a set of subsystems, is more heterostatic than homeostatic. It means that, in certain moments, there is a threat to the ultimate balance of the given system, which destabilises subsystems in order to keep balance on the higher level. It could be described as divide et impera strategy, that despite many changes in today's world 
still seems to be in place, especially when looking at the influence of the major players for regional systems like Middle East (Fiedler, 2015: 155-165) and Central Asia (Baranowski, 2016: 286-306). Just like an organism which increases its temperature when infected, a major actor in the given system might be causing conflicts between subsystems in order to keep its position. While the middle level systems - with their inner control mechanisms striving for homeostasis - the strongest actor in the international system is striving towards destabilisation of the system, increasing the entropy, and that other systems work very hard to overcome. This is why chaos is achieved relatively easier then order. Once self-regulatory mechanisms are disabled and entropy is being increased, chaos emerges. The fall of Muammar Kaddafi, and contemporary picture of Libya being its consequence, is a perfect example of such conduct.

Polish cyberneticist, Mazur dedicated more than 20 years of his professional career to provide complex explanation of the feedback loops and self-regulatory mechanisms within the system. If one system is impacting the other one (via information or energy or both) the latter can defend itself from unwanted change, up to the moment when critical level increases and the system is out of balance causing its structure to decline. Below I enclose schemes of the feedback processes (Scheme 1 and 2) and self-regulatory reactions (Scheme 3 and 4) (Mazur, 1996: 25-32):

Scheme 1. Negative feedback loops (Mazur, 1966)

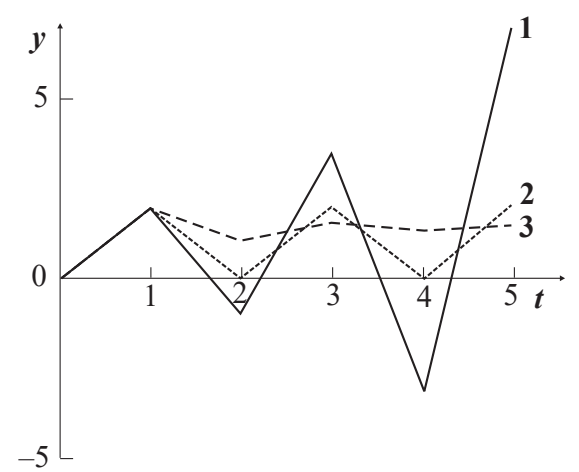

Scheme 2. Response for negative feedback

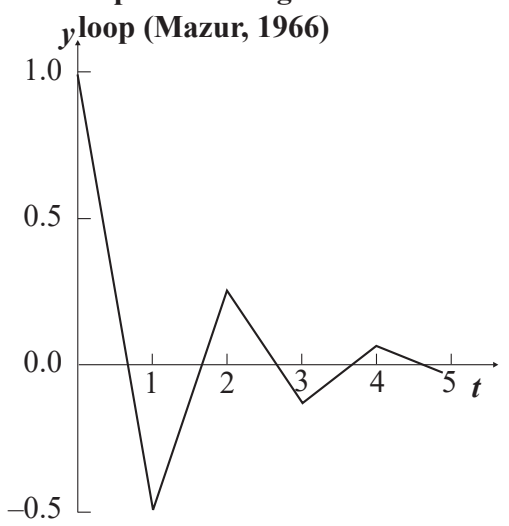

1. Divergent feedback; 2. Constant; 3. Convergent

Gałganek argues that hegemon (the strongest actor in the system) is interested in silencing of others in order to keep the system in check (Gałganek, 1992: 71). Completely opposite examples can be found in the history of the international relations too, however. If Gałganek is right the - system should be seen as homeostatic, if he is wrong it could be the other way around - and the system should be considered as heterostatic. All in all, it seems that the answer whether the international system is homeostatic or heterostatic is inevitably connected to much more difficult question and that is: are there different mechanisms in place on different levels. That might be a trivial comparison, but I would say it is quite like comparing Newton's physics with its quantum counterpart. Both are real depending on spectrum. 
Scheme 3. Positive feedback loops (Mazur, 1966)

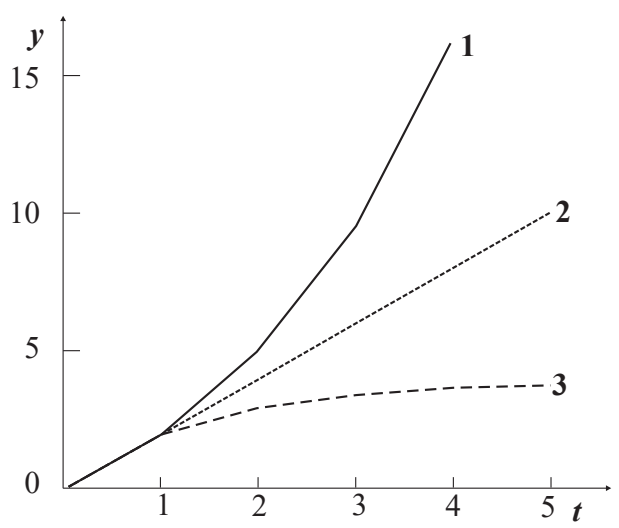

Scheme 4. Response for positive feedback loop (Mazur, 1966)

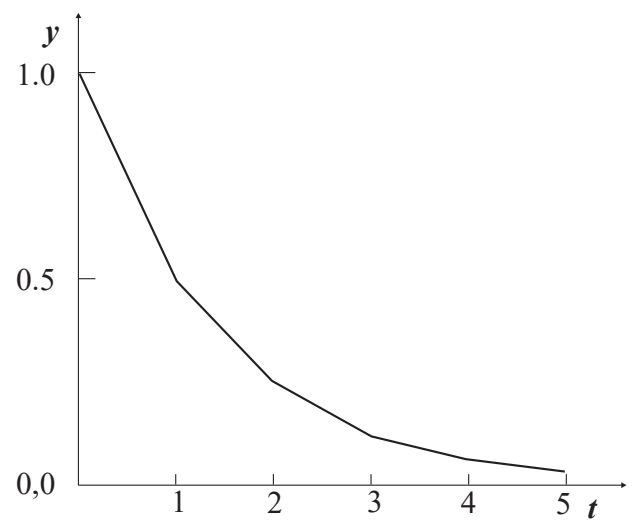

\section{OSCILLATIONAL OR FLUCTUATIVE?}

There was a huge amount of effort put into research on political system evolution. Knowledge in that matter is still incomplete and probably it will always remain as such. Despite the fact that it reveals some ways to interpret change within the structure. The problem here is the method of measurement empirical data that could be analysed is always incomplete and quite subjective as well. In Poland, Gałganek can be described as a pioneer of the changing scope of research in the field of the international relations. In his book from 1992 entitled: "Change in Global International System. Supercycles and Hegemonic War", he has focused on the question fundamental to the entire discipline: is the world of international relations repetitive? Gathered material proves that indeed there is some level of repetitiveness in relations between global political and economic system, that together Gałganek called spercycle (1992: 113). In his work, he takes into account finings of Modelski, Giplin and Wallerstein, binding them together and developing into something new. Wallerstein argues that certain correlation occurs between the system when we look at it in a long perspective (quite like a longe duree idea). "In international system we can find two full super-cycles as a form of synchronisation of political and economic level. From the international system's point of view, key periods are turning-point-phases of super-cycles. Those are periods of interference phases of hegemonic war of political cycle, and changes within long inclining or declining phases of super-long economic cycle" (Gałganek, 1992: 71).

Justification for the given order of changes (regural - cycles or irregular - fluctuative) can be explained on the basis of approach one adopts. Once more, the concept of order of the change is connected to the question of nature of the mechanisms occurring on the given level of the international system. By courtesy of Gałganek, I am able to cite Burton: "Basic lack of orthodoxy can be found in the approach towards the change. Dynamic nature of international relations is a vital part of reality. Because of that, no theory can be held as valid, if it does not take into account the quick technological, so- 
cial and political advancement of the environment, which nations need to live in peace. At the same time sole mechanism of fundamental change, that is possible in context of power-based politics, is war [...]. It is no surprise then that international relations have a tendency to operate with statistic-based terms, and stability is interpreted as an ability to keep status quo. Dynamic approach towards international relations confronts researcher directly with no alternative to understanding the war as an only possible mechanism of change" (1965: 71-72).

With the constantly increasing amount of information, accurate measurement would be only possible once the new technologies grasping those advancements (like BigData) are at anyone's disposal. Until they are not simplified, the international relations researcher has very limited possibilities, as Burton said. Researcher adopting a single perspective - either economic or military one - will be unable to produce satisfactory results which could answer the question of order of the change. Two-dimensional model created by Gałganek is a great starting point for further research, in which the changes of information volume could be taken into account.

The study of the structure of the international system is also connected with the study of dynamics of the structural influence on the specific actors within the given system. In an ideal situation, those changes could be identified (and favourably quantified), which would enable a more accurate determination of the researched influence. Waltz argues that action undertaken by an actor is in fact the result of its position within the system (which means what is one's share in global system's correlator, speaking from cybernetics perspective). The growing entropy would therefore mean that change is about to happen in the structure of the system. "In other words: the system encounters problems it can no longer resolve, and this causes what we may call systemic crisis" (Wallerstein, 2004: 76). By simply noticing some regularities we could imply that system is indeed cyclical, but without empirical analysis such statement is highly risky and subjective.

Cybernetics gives us information about durability of the system by modelling the dispersion of energy and information within the system. Thanks to Mazur's work, we have a very broad picture of system dynamics, and if accurate variables could be identified maybe following changes could become noticeable immediately. Mazur shows this dispersion as an integral (Scheme 5).

Indicators $P$ are for "power" type that system transforms in time $(t)$. Its ability to influence environment (surroundings) is proportional to how much of coordination power $\left(P_{k}\right)$ it has at its disposal (it is a difference between $P_{d}$ for dispositional and $P_{r}$ - power used for basic functions that cannot be turned off without immediate death of the system). If for $P_{k}$ we take military spending - the scheme is accurate, all in all hegemonic position of USA is secured by its military budget and the fact that it spends more than rest of the world combined. It means that it has the most power to shape its surrounding - the international system. In Mazur's theory (cybernetic theory of autonomous systems 1966) system goes through phases of growth and decline. It perishes when it becomes insufficient enough and its entire energy $\left(P_{d}\right)$ is equal to power used for basic needs $\left(P_{r}\right)$. We also know that system grows stronger when its growth is suppressed. On the flipside, more and more energy is dedicated to system's basic needs (welfare state) until the moment when there is nothing left to give away, demand is not 
Scheme 5. Distribution of power within the system in time

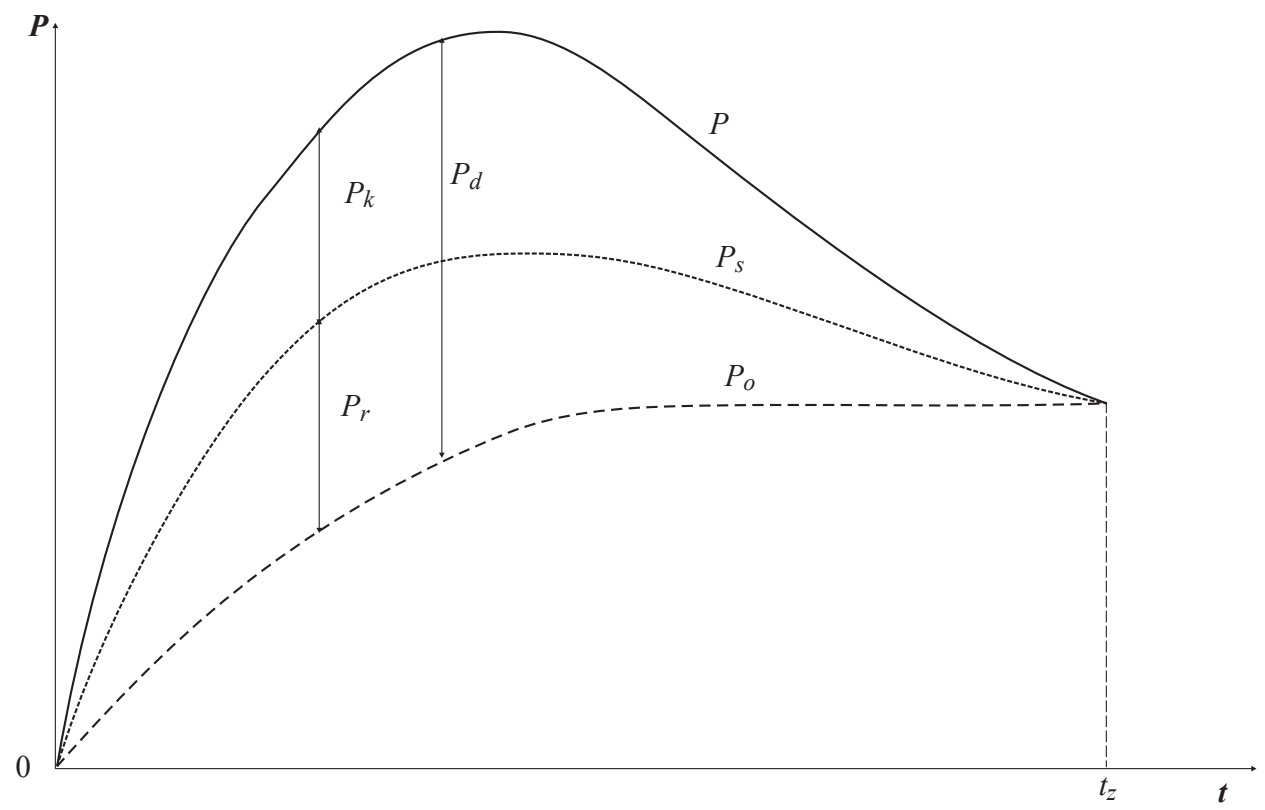

Source: Mazur, 1966.

declining, and system becomes bankrupt (in power terms). Below I enclose schemes of system growth with suppressing environment (Scheme 6) and non-suppressing environment (Scheme 7).

Scheme 6. System with suppressing environment

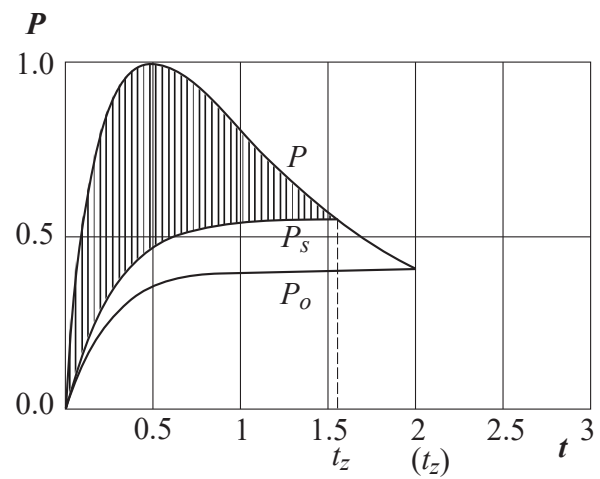

Scheme 7. System with non-suppressing environment

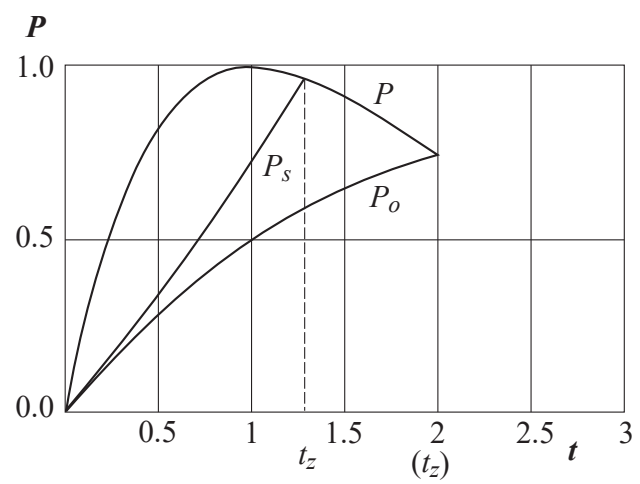

Source: Mazur, 1966.

The ultimate cause of the fall of the system is similar in both cases: for the sake of expanding need for power to support the system, it is growing, and in the case of its 
lack, the - system falls under its own weight and ends its structural existence (usually by transforming into a different system: the UK after its second hegemonic cycle did not cease to exist, but its ability to shape the environment has declined significantly). Different example of the same scheme is given by Gałganek: "Mark Elwin advocates that imperial costs of Chinese Empire were growing geometrically when its assets were growing only arithmetically" (1992: 37). It is a problem of a system with nonsuppressing environment which leads to death in the quickest possible way.

$$
* * *
$$

Waltz, father of the neorealist paradigm, says that anarchy is a structural quality of international system (understood as lack of relations of dependence, at least officially). At the same time he underlines that the elements of the system are not equal (Waltz, 2010: 135). If Waltz is right, international system has a structure of autonomous system with some or even all its features. It does not have an organiser, however, elements inside are somehow orderly. Studying structure of the system is not possible without looking at the structure of the subsystem's spatial and temporal context (understood as system environment and its dynamics) and structural context (relation of its elements). Discovering nature of international system structure is connected with the question that was asked many times in this paper: are mechanisms different on different levels of the structure of the system?

It is not said that cybernetics has all the answers, but it can certainly help to unravel some mechanisms beneath the visible surface. As an scientific approach, cybernetics " $[\mathrm{g}]$ ives hope to create basic methods, thanks to which we will be able to tackle various deseases - psychological, social, economic - that are still conquering us by its internal complexity" (Ashby, 1961:21). Powermetrics is also a promising field, that has already added some principals of cybernetics into its methodology. One example of that is Sułek's method, which helps to determine the power of the given state from the stream and static perspective (Sułek, 2004: 102-113). Another starting point could be method of entropy measurement introduced by J. Kosscecki, although it is inevitably connected with the necessity of having the access to numerous historical and contemporary databases (Kossecki, 1981: 446-463). Despite the fact that Wiener warned against difficulties that my occur when cybernetics and social sciences meet (Wiener, 1971: 51), more research needs to be conducted with the use of a single paradigm; the alternative - sliding from one theory to another - does not seem to work so far.

\section{REFERENCES}

Ashby R. (1961), Wstęp do cybernetyki, PWN, Warszawa.

Baranowski P. (2016), Rewizja ładu w globalnym systemie międzynarodowym a polityka USA w Azji Środkowej, in: R. Fiedler, T. Wallas, Unia Europejska wobec Azji Centralnej, Poznań.

Bertalanaffy von L. (1984), Ogólna teoria systemów: podstawy, rozwój, zastosowania, przekład E. Woydyło-Woźniak, PWN, Warszawa. 
Burton J. (1965), International Relations. A General Theory, Cambridge.

Campbell Biology Tenth Edition (2017), Poznań.

Czaputowicz J. (2012), System międzynarodowy jako poziom analizy w nauce o stosunkach międzynarodowych, in: Poziom analizy stosunków międzynarodowych, eds. E. Haliżak, M. Pietraś, Lublin.

Donaj Ł. (2017), Teoria szarych systemów a prognozowanie w naukach społecznych. Przyczynek do dyskusji, „Przegląd Strategiczny”, No. 10.

Falconer K. (2003), Fractal Geometry, Methematical Foundations and Applications, Chichester.

Fiedler R. (2015), US Policy Towards Egypt versus other Entities, in: Transformation Process in Egypt After 2011 - The Causes, Their Course and International Response, eds. R. Fiedler, P. Osiewicz, Berlin.

Gałganek A. (1992), Zmiana w globalnym systemie międzynarodowym. Supercykle $i$ wojna hegemoniczna, Poznań.

Gardocki S. (2012), Teoria systemów a poziom analizy w nauce o stosunkach międzynarodowych, in: Poziomy analizy stosunków międzynarodowych, eds. E. Haliżak, M. Pietraś, Lublin.

Gomółka Z. (1996), Elementy ogólnej teorii systemów, Szczecin.

Haliżak E. (2012), Poziom analizy w nauce o stosunkach międzynarodowych, in: Poziom analizy stosunków międzynarodowych, eds. E. Haliżak, M. Pietraś, Lublin.

Heywood A. (2006), Politologia, Warszawa.

Kossecki J. (1981), Cybernetyka spoleczna, Warszawa.

Kraus-Mozer B. (1992), Metodologiczne problemy wyjaśniania w nauce o polityce, Kraków.

Mazur M. (1966), Cybernetyczna teoria układów samodzielnych, Warszawa.

Sułek M. (2004), Metody i techniki badań stosunków międzynarodowych, Warszawa.

Wallerstein I. (2004), World-Systems Analysis. An Introduction, Durham.

Waltz K. (2010), Struktura teorii stosunków międzynarodowych, Warszawa.

Wiener N. (1960), Cybernetyka i społeczeństwo, Warszawa.

Wiener. N. (1971), Cybernetyka, czyli sterowanie i komunikacja w zwierzęciu i maszynie, Warszawa.

\begin{abstract}
Author discussed various theoretical difficulties connected with the concept and dynamics of international system. He claims that many misunderstandings in political science, including inaccurate predictions as well as real-time-analysis, are caused by lack of precise theory of international systems within international relations as well as failure to adapt some concepts regarding systems from General System Theory, Cybernetics, Chaos Theory and Catastrophy Theory (or paradigm of complexity as a whole), that seem to be used with success in other disciplines like biology or physics. The author proposes five essential dimensions where structure of the system could be successfully measured. He argues that systemic approach based on various theories concerning complexity can lead to resolving some essential questions concerning the nature of the system with the most important one concerning mechanisms at various levels of the system, need to be answered.
\end{abstract}

Keywords: international system, cybernetics, realism, complexity 


\section{O NATURZE SYSTEMU MIĘDZYNARODOWEGO}

\section{STRESZCZENIE}

Poniższy artykuł dotyczy wybranych teoretycznych problemów związanych z koncepcją oraz dynamiką systemu międzynarodowego. Autor stwierdza, iż wiele nieścisłości istniejących w nauce o stosunkach międzynarodowych na temat systemu międzynarodowego wynika $\mathrm{z}$ braku ścisłej teorii systemu międzynarodowego oraz braku zaadaptowania koncepcji pochodzących z ogólnej teorii systemów, cybernetyki, teorii chaosu oraz teorii katastrof (lub ogólniej: paradygmatu złożoności), które z powodzeniem są stosowane w innych dyscyplinach, takich jak biologia czy fizyka. Autor proponuje pięć wymiarów, gdzie dokonywać się może pomiar struktury systemu oraz jego zachowania. Autor zakłada, że podejście ściśle systemowe oparte na paradygmacie złożoności może prowadzić do odpowiedzi na ważne pytania dotyczące natury systemu, w szczególności jeśli chodzi o tożsamość mechanizmów działających na różnych poziomach systemu.

Słowa kluczowe: system międzynarodowy, cybernetyka, realizm, kompleksowość 
